\title{
Cultural Teaching in English Class of University*
}

\author{
GUO Yu-hua \\ Binzhou University, Shandong, China
}

\begin{abstract}
Since 1990s, we have paid more and more attention to application of cultural teaching in SLA (Second Language Acquisition). In China, this tendency shows the improvement of teaching environment and methods in English teaching, that is from the past onefold teaching of grammar to the involvement of all aspects of cultural backgrounds. Educators serve as a bridge in cultural transmission; they not only have to measure the proportion of cultural backgrounds in language teaching, but also have to make use of the influence of culture to give students all-round educations. This paper presents an overview of the relation between culture and English teaching, emphasizing the importance of culture in SLA. The ultimate goal of cultural teaching is to truly understand the culture and thinking mode of foreign countries so as to learn the second language better.
\end{abstract}

Keywords: cultural teaching, SLA, cultural influence, cross culture

\section{Introduction}

Introducing cultural teaching into English class can help students to achieve a high level goal in English learning - communicating in English. Letting students understand the relation between the language and culture and be sensitive to the differences of cultures in intercultural communication is vital to English teaching. This paper deals with a series of teaching methods in English class from the aspects of language, culture, and relevant learning methods based on the features of English learning: start from the language and culture and let the students experience the differences of thinking mode between West and East; introduce a kind of culture by using the idioms and improve the students' communication skills in English; let the students realize to fully master a language they need to understand the deeper basis of a language-culture, they need to figure out the history and cultural backgrounds of English speaking countries, such as the social system, historical development, religious belief, national psychology, customs and science and technologies, etc.

\section{The Relation Between Language and Culture}

We must firstly figure out the concepts of language and culture if we want to know the relations between language and culture.

\section{The Concept of Language}

People give different exposition from different angles. American sociolinguist Sapir gave a high generalization of language:

Language is a system of phonetic symbol that expresses thoughts and emotions. As a special human symbol system,

\footnotetext{
* Soft Science Research Project: 2016 Binzhou City "On Interactions between Optimization, Upgrading of the Marine Industry Structure and Practical Business English Talent Training in Binzhou" (No. 2016BRK03). GUO Yu-hua, lecturer, M.A., Foreign Language Department, Binzhou University, China.
} 
language is human's thinking tool and the most important communication tool for human beings. Humans use language to communicate and the language record the experience of labor and life of predecessors, the history of a nation, as well as the thinking mode of a nation; language expresses a nation's cultural mentality. (Sapir)

Same as this, Brooks also thought that:

Language is a symbol system consists of grammar, vocabulary and voice. This system consists of syntax-the relationship among symbols, semantics-the relationship between symbols and their meanings and pragmatics-the relationship between symbols and their users. But language is not a close system; it is connected with social cultures. (Brooks)

Therefore, from sociolinguist's view, language is the expression and carrier of national cultures and social cultures are the basis and premise of language development. Language acquisition theory holds that language as a tool for knowing the world, it reflects the methods to know the world, and meanwhile, language also reflects national history and the development of culture and gives a concentrated reflection of cultural traditions and value orientation.

From the above mentioned, we can define language as: a special human symbol system that consists of voice and meaning, the medium for human to change thoughts, and also the tools for human to know and change the world. At the same time, language is also a social phenomena; it comes into being at the same time with the forming of society and develops with the society. Seen from the structural characteristics, language is a symbol system that consists of phoneme, morpheme, vocabulary, sentence, phrase, and chapter. Seen from functional characteristics, language is the tool of human communication.

\section{The Concept of Culture}

Culture is a sophisticated social phenomena and it pervades all aspects of social life. Linguists deem culture as the combined material wealth and spiritual wealth that human beings have created through their development and history.

Socialists and anthropologists think culture as a society's special belief, customs, systems, goals, and technologies. For instance, Edward Tyler (1871), British cultural anthropologist, put forward the idea that culture is the central concept in his Primitive Culture in 1871. He deemed culture as a complex that contains knowledge, belief, art, moral, law, customs, and other abilities and habits that learn from social life. From the above mentioned, it can be inferred that culture is the total material and spiritual wealth that human gained through their development and history and culture contains material culture, system culture, and psychological culture. Any nation is based on its own history, geography, and social structure.

Therefore, different nations have different culture due to their different geographies, environments, politics, economic systems, and behavior patterns. That is culture has distinct national characteristics; culture is a mark of the different nations.

\section{The Relationship Between Language and Culture}

Language is a part of culture. If we see the culture as a whole, then the language is a part of human culture. However, the language plays a special role in our culture and it can be seen as a social phenomenon, a communication tool of human, and a medium linking human and culture together. The language evolves with the formation and development of human society. The language and culture come into being and evolve simultaneously: Language is the precondition of formation and development of culture and culture means nothing without language. We learn English with the purpose of communication, presenting China to the world. 
Meanwhile, when we learn foreign languages, we should learn to see what foreigners see and feel what they feel. We must contrast the difference between East and West. We cannot truly master English if we do not study this cultural difference.

If we see from the perspective of the relationship of language and culture, then the language will be both an important carrier of culture and also a form of culture. Therefore, English teaching is not merely language teaching and it should broaden students' horizon, teaching them culture and customs of English speaking countries.

Learn a foreign language and not know its culture, you learn only some symbols without meanings. It will be difficult for you to use it, and you will not rightly speak this language when using it. Language teaching class is the bridge linking language and culture together. This is especially the case in China, for the class is the main place for learning foreign language.

So the English teaching should involve the teaching of cultures.

\section{The Relationship Between Language Teaching and Cultural Teaching}

Culture and language affect and interact with each other. Language teaching and cultural teaching are two aspects of foreign language teaching. Language teaching is synchronic, complementary, and compatible with cultural teaching.

\section{Synchronization}

The synchronization of language teaching and cultural teaching means in language teaching, teachers should also teach culture. Language is inseparable from cultural teaching. When students gain language skills through study, they should also gain pragmatic competence. Therefore, the synchronization of language teaching and cultural teaching in English teaching is necessary.

\section{Complementarity}

Language teaching and cultural teaching supplement each other. Language is the carrier of culture and the unique key to culture. Students should learn language first if they want to know a certain culture. Therefore, language teaching is the premise of cultural teaching. Meanwhile, culture is the basis of language. Language develops based on culture. If learners want to express their ideas idiomatically, they should learn culture of this country. At the same time, language teaching without cultural background is boring and dull and it cannot activate learners' initiative and consciousness to learn the language.

\section{Compatibility}

Language is inseparable from culture. So the compatibility between language teaching and cultural teaching is inevitable. The separation of language from culture is against the teaching rules. Language is a "culture of symbols" and it is a representation of cultures; meanwhile, culture is a kind of "humanization" containing symbols. Culture and language affect and interact with each other; they are compatible and complement each other.

Language teaching and cultural teaching have synchronization, complementarity, and compatibility. Therefore, language teaching and cultural teaching are different aspects of foreign language teaching; cultural teaching is supplement to language teaching and it is not a relative independent system against language teaching. 


\section{The Necessity of Culture Teaching in English Class}

Language is a very important part of culture. It is not only a system of symbols, but also the carrier of culture. Language is the material outer covering of mankind's thought activity, carrying the information of cultures and reflecting the thinking mode of a race. Language is limited by culture, for culture deep-rooted in language. People are restricted by the culture when using their language. The expression form of human language is conditioned by the customs, way of act, values, thinking modes, religious belief, national psychology, and characters, which are the basis for language. Teachers should help students improve their sensitivity towards cultures. Teachers could take advantage of students' interests of knowing other cultures to provide the basis for studying the language. Combining the language and culture together and putting the language under the culture background, when teaching the language we should also teach cultures. Those cognition and practice began at the earlier 1970s. Communications among countries and the conflicts were surged at 1970s at international society. It is especially this case in Europe, EEC (European Economic Community) put forward "cooperation of teaching and culture" and "give priority to the new language teaching method" for the "interdependency". Therefore, unprecedented priorities are given to the language teachings and the main aim for learning a language is communication, which is a social behavior. So in English teaching, there must be teaching of culture background. Based on the above-mentioned theories and cognitions, in the past two decades, culture has been introduced into classes when the emphasis of language changed from grammar and form to function and content and when the focus of foreign language teaching changed from the teaching of grammar and words to the training of communication skills.

\section{The Influence of Cultural Teaching in English Class Upon English Learning}

\section{Culture and Words}

Language is a mirror of culture; each nation has it own special culture. The rich vocabulary in English is the concentrated embodiment of its profound culture. Therefore, it is necessary for teachers to help students understand and master the meaning of English words and how to use them. In English teaching, teacher could start from the social cultures of English speaking countries, revealing the culture and national conditions and teaching students to accurately master the meanings of words and communication skills, avoiding all kinds of misunderstandings. For example, some words are same in literal meaning and cultural connotations-fox means someone is cunning. These kinds of words are easy for us to learn. In addition, there are some differences in English and Chinese, for example, the non-equivalence in the title of interpersonal relationship. Sister could mean elder or younger sister.

\section{Culture and the Reading Comprehension}

Communication abilities are shown not only in oral English but also in reading comprehension. For most of us, we learn the English society indirectly from the literatures and newspapers. In the light of the relationship between cultural teaching and language teaching, teachers should involve some relevant cultural knowledge in reading teachings. According to the research of reading comprehension, the key to understand the article is to rightly use background knowledge to fill up the vacancy of the article, making it a whole with the article. The lack of necessary cultural background knowledge could lead to the disconnection of the context, wrong prediction of the context, and misjudgment. In reading teachings, cultural elements could be obstacles for students in reading comprehension. Lack of the relevant background knowledge could lead to obstacles for reading. For instance, 
I teach because I enjoy finding ways of getting myself and my students out of the ivory tower and into the real world. I once taught a curse called "Self-reliance in a Technological Society". My 15 students read Emerson, Thoreau, and Huxley. Literally, students only know that the author let his students to read works of Emerson, Thoreau, and Huxley.

Why the author asks his students to read their works? None of his students know that. So when I asked "Why did the author ask his students read Emerson, Thoreau, and Huxley", they could not answer. Under this circumstance, students need to know the background of the three authors in order to read their works. In The American Scholar, Emerson asked students to study the nature. In Self-reliance, Emerson stressed the importance of independence. In 1854, Thoreau built a house in forest and stayed there for two years. He has led a dog's life there for two years. He published his masterpiece Waldon in 1854 based on his real experience in forest. In Waldon, he revealed his opinion about nature and life. Huxley also showed great interest about nature in his books. He held that the human's pursuance and possession of material wealth is at the cost of their personal freedom and their respect for nature. In In Island, he expressed his utopia ideals of carefree people live harmoniously with nature. After getting the background of three authors, students know that their common ground is that they show great interest in nature and emphasize the personal survival skills. Therefore, students will know that author wants them to know the relationship between human and nature as well as how to survive by themselves in industrious society by reading the works of three authors.

\section{Culture and the Historical Background}

Lack of the knowledge of the history of England and America will lead to the failure to understand the whole article. Take the Unit 2 of Book Three of College English Intensive Reading as an example. The story is as follows: During the Civil War in Southern Federation, an ordinary woman whose brothers either died in the war or be captured with her husband by Northern forces. However this, she carefully took care of a Northern military officer whom she found nearby her house until he recovered instead of disclosing his identity and finally sent him to his army. This article was based on the Civil War. In order to fully understand this article, students should get to know this history, such as the cause and nature of the war, or else they cannot understand the Northern army, Southern army, Southern federation, and why Northern forces were against the Southern federation. Firstly, why Northern and Southern sides were at war with each other? The abolition of slavery was one of the main reasons. Northern and Southern sides had divergence of views about slavery all along. Northern side developed capitalism while slavery economy dominated the Southern part. Slavery restricted the development of the American economy, so most of Northerners wanted to abolish slavery while Southern slave owner firmly against it. Another reason was that the federal government was suffering the split when Lincoln was in office. Lincoln was famous for his against at slavery so Southern slave owners were in panic when he was elected. In Southern part, seven states broke away from federal government and formed the Confederate and another four were trying to follow suit. Lincoln waged the war to abolish the slavery to promote the development of America as well as to maintain the national unity. By fully understanding the history and nature of the Civil War, students could get overall knowledge of this article and know deeply that the final goal of the war was for the future and development of America and the Americans were the beneficiaries.

In addition, it also related to background knowledge, multi-media cultural teachings, experience and understanding of cultural knowledge, experience of English cultures, cultural teaching with the comparison of English and Chinese cultures, enhancing of the comparison of differences between English and Chinese cultures and introducing knowledge with material object and cultural teachings with the help of Internet. 


\section{The Method of Cultural Teaching in English Class of University}

English teaching in university mainly contains learning needs analysis, teaching objectives, teaching process, and teaching strategies based on characteristics of learners. If we want to find real solutions to problems of cultural teaching lag in university teaching class, besides teachers should have new teaching concept, they should also purposefully and systematically take effective measures to incorporate cultural knowledge into the foreign language teaching system from the perspective of students, teachers, outlines, textbooks, and content of courses as well as efficiently combine cultural knowledge with language knowledge. Teachers should step by step foster the students' cultural appreciation, enabling them to transform cultural knowledge into practical intercultural communication skills.

\section{Cultural Teaching Is Student-Centered}

Language teaching is student-oriented; student is the learner of culture as well as practitioner of intercultural communications. Due to individual differences and experiences, everyone has different cognition about and demand for culture of the target language. Therefore, before the curriculum design, teachers should make questionnaire survey and interview to know students' need of cultural knowledge. Through the analysis of students' need, teachers can integrate students' need into curriculum design, textbook compilation, as well as the selection of textbooks, which will arouse students' interest and enhance the comprehensive cultural awareness.

\section{Teachers Should Enrich Their Own Cultural Knowledge Initiatively}

In English teaching, teachers' cultural awareness plays an important role in fostering students' intercultural communication skills. Only teachers have strong ability of intercultural communication skills can they effectively perform intercultural communication in class. Teachers' weak cultural awareness in intercultural communication will definitely lead to students' lack of intercultural communication skills. In this case, it is necessary for teachers to master specialized knowledge as well as profound cultural awareness. In class teaching, therefore, foreign language teachers should enrich Chinese and Western cultural knowledge, enhance their cultural awareness, and make themselves a good example for students to follow.

\section{Conclusion}

All in all, English is a tool for us. The aim of learning English is not only to better master it, but also to successfully communicate with other culture. It is impossible to strengthen the communication skill without the background knowledge. Therefore, it is imperative for teachers to enhance their teaching skills and broaden their horizon in daily teachings. Teachers should systematically and consciously teach cultural background knowledge, foster students' consciousness of intercultural communication, and value the differences between Chinese and English culture. Only in this way can teachers cultivate high-skill talents that conform to the needs of society development.

\section{References}

GU, G. (2004). Foreign Language and cultural studies. Beijing: Beijing Institute of Technology Press.

LIU, R. Q., \& ZHUANG, L. (2000). The understanding and transcending of cultural difference. Beijing: Foreign language Teaching and Research Press.

The relationship between culture and foreign language learning and teaching from foreign language culture (1998). Beijing: Foreign Language Teaching and Research Press. 
HU, W. Z., \& GAO, Y. H. (1997). Foreign teaching and culture. Beijing: Foreign Language Teaching and Research Press.

LIAO, G. R. (1999). Some questions of culture introduction in reading teaching at the preliminary stage for English majors. Foreign Language World, 1, 39-42.

Anderson, B. (1984). Cross cultural schema and reading comprehension instruction. London: Verso.

ZHANG, A. D., \& ZHANG, X. (2002). The cultural awareness and cultural input in foreign language teaching. Foreign Language and Their Teaching. 